\title{
Sustainability Reporting Practices In Portugal: Greenwashing Or Triple Bottom Line?
}

Diane H. Roberts, (E-mail: robertsd@usfca.edu), University of San Francisco John P. Koeplin, (E-mail: koeplin@usfca.edu), University of San Francisco

\begin{abstract}
This paper examines the status of sustainability reporting in Portugal. The Global Reporting Initiative's (GRI) guidelines for sustainability reporting is an initiative that attempts to create a paradigm of triple bottom line reporting that encompasses the economic, environmental, and social performance of business. Measurement and reporting of environmental and social aspects are in their infancy compared to financial/economic reporting. The objective of the GRI's framework is to elevate environmental and social reporting to the level of financial reporting by developing reporting principles and information qualities similar to those used in corporate financial reporting. In the post-Enron corporate reporting environment, such credibility may be tarnished and lead stakeholders to suspect corporations of greenwashing their reputations by issuing reports that are environmental window dressing.

Currently 860 companies in a variety of industries worldwide are voluntarily listed as using the guidelines on the GRI's web site; however, only five are from Portugal. Two of the five companies are GRI organizational stakeholders and one is listed as reporting 'in accordance' with the guidelines. Content analysis will be used to examine both the quantity and quality of information in the GRI reports of Portuguese companies. An additional issue regarding the transparency and credibility of the information provided is whether the reports have been verified (a more generic term than audit used for a similar assurance-type service relative to GRI Reports). The results of the content analysis will be used to shed some light on whether the companies generating these reports are bridging or widening the sustainability reporting expectations gap between companies and stakeholders.
\end{abstract}

\section{INTRODUCTION}

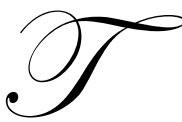

he Global Reporting Initiative (GRI, 2000) framework for sustainability reporting addresses three components: the economic, environmental, and social aspects of an entity's operations. It is a transnational attempt to extend the credibility of financial reporting into social responsibility areas by utilizing similar standards for preparation and reporting. The GRI does not endorse any national GAAP in the economic reporting guidelines.

Greenwashing is defined as the structuring of corporate disclosures regarding environmental matters so as to maximize perceptions of legitimacy. The term implies creative reputation management to "hide deviance, deflect attributions of fault, obscure the nature of the problem or allegation, reattribute blame and, finally, need to appear in a leadership position" (Laufer, 2003, p. 255).

Corporate social responsibility disclosures may aid companies in achieving organizational legitimacy. Neu, et al. $(1998,266)$ note that "intersection of fractionalized social values, well-organized and vocal interest groups, and the necessity to operate in a competitive global economy has made organizational legitimacy increasingly important yet more difficult to obtain." Companies may achieve strategic goals such as appeasement of dissident stakeholders or reduced governmental regulation by providing social responsibility reporting. 
The five companies in the sample are: Brisa S.A., Delta Cafes. EDP (Energias de Portugal), Portugal Telecom, and Sonae Sierra. Each company's most current report was obtained via the Internet and examined. Reporter listing on the GRI website is voluntary and some Portuguese companies may issue environmental reports but are not listed on the GRI website. The actual reports of the companies were compared to the "in accordance" requirements of the GRI Reporting Guidelines.

The role of the auditor in GRI Reporting continues to evolve and is an important practice opportunity (Beets and Souther, 1999). PricewaterhouseCoopers, one of the Big Four CPA firms, is a charter sponsor of the GRI's secretariat in Amsterdam (PWC, 2002). No environmental audit standards exist comparable to financial auditing standards but the GRI has provided guidance for the form and content of the verifiers' statement or report. Verifier is a term that does not equal accountant or auditor, thus accountants may face some competition offering this type of assurance service.

The remainder of this paper is organized as follows. The next section provides the background of the Global Reporting Initiative (GRI) and discusses the theory relevant to social reporting by corporations. The following section details the methodology used and the evaluation of the reports of all Portuguese companies using the GRI framework. The final section discusses the findings, limitations, and implications.

\section{SOCIAL RESPONSIBILITY ACCOUNTING}

Social responsibility accounting provides information to users regarding a company's resource usage, any related economic externalities, and social contributions that affect current and future generations [Gordon, 1998]. Environmental accounting is thus a part of social responsibility accounting and not valuation of natural resource assets. Instead it deals with how environmental issues affect traditional accounting subdisciplines [Sefcik, et al., 1997]. One objective of both social responsibility and environmental accounting is to improve decision making by more accurately reflecting the complete cost of doing business.

The considerable need for reporting standards for this type of disclosure is seen in CorporateRegister.com's rules for submitting a report to be referenced on their site.

We have had to take a view on what constitutes a 'report', as we have received many brochures and other publications. In the absence of widely accepted definitions, we tend not to feature publications which are sales brochures, have no reference year, no hard data and no statement of policy, regardless of whether the issuing company terms them a 'report'. (CorporateRegister.com, 2004)

Global Reporting Initiative (GRI) Standards were developed to provide credibility and meaningful content for sustainability reports. The GRI was jointly founded by the Coalition for Environmentally Responsible Economies (CERES) and the United Nations Environment Program who are both still involved with the GRI (PWC, 2002). As the GRI is attempting to address the information needs of stakeholders, multiple stakeholders were consulted in the development of the GRI Guidelines. These stakeholders include corporations, non-governmental organizations (NGOs), consultancies, accountancy organizations, business associations, and universities. Initial organizational meetings were held in fall 1997 and in 2002 establishment of a Secretariat in Amsterdam was announced.

The G3 Standards were not ratified until October 2006, thus the Portuguese companies prepared their reports using the Guidelines issued in 2002.

The underlying principles of GRI Reporting are familiar from accounting: reporting entity, reporting scope, reporting period, going concern, conservatism, and materiality (GRI, 2000). A conventional annual report covers only the well-defined economic domain but the GRI Report may cover all three areas or focus on a subset, thus the scope of the report must be clearly defined. Reporting periods of one year may be too short to capture many important environmental and social impacts such as employee social conditions or environmental contamination (GRI, 2000). When assessing going concern, the company should consider not only the audit opinion, but also the impact of prospective legislation, ability to fund necessary remediation, internal and external risks, and consequences of moving 
towards operations compatible with sustainability. Conservatism asks companies to present both the positive and the negative aspects of their operations. Materiality is perhaps more broad than in financial accounting as it is dependent upon what is relevant to either the reporting organization or their external stakeholders. As such it is dependent upon both its magnitude (monetary significance in financial accounting) and its nature or circumstance of the event.

The qualitative characteristics for GRI Reporting are also drawn from accounting: relevance, reliability, clarity, comparability, timeliness, and verifiability (GRI, 2000). To be relevant the information should be presented in its economic, environmental and social context and with appropriate benchmarks. The prudence principle is emphasized to ensure that uncertainty is considered appropriately. Companies are encouraged to not report uncertain outcomes prematurely and to not misrepresent positive progress as sustainable (GRI, 2000).

GRI or Sustainability Reports are voluntary and there is diversity in the submitted reports. Appropriate indicators for a specific company should be selected with active consultation of key stakeholders (GRI, 2000). Few organizations listed as GRI reporters have conformed/provided sufficient data to be considered "in accordance" reporters. Verification by an independent verifier is optional and not a requirement for "in accordance" reporting. GRI Guidelines (2002) specify the following report content for 'in accordance" reporting:

- $\quad$ Vision and Strategy, including CEO Statement

- $\quad$ Profile of Reporting Organization

- $\quad$ Governance Structure and Management Systems, includes discussion of stakeholder engagement efforts

- $\quad$ GRI Content Index

- $\quad$ Performance Indicators- core indicators in

- $\quad$ Economic (10 core indicators)

- Environmental (16 core indicators)

- $\quad$ Social: 24 total core indicators distributed as follows.

- $\quad$ Labor Practices and Decent Work (11 core indicators)

- $\quad$ Human Rights (7 core indicators)

- $\quad$ Society (3 core indicators)

- $\quad$ Product Responsibility (3 core indicators)

The GRI has been tightening the requirements for listing as an "in accordance" reporter on their website by requiring a GRI organization review of the organization's report prior to such listing.

Independent verification is one way that quality, usefulness, and credibility of a company's social responsibility reporting can be enhanced. Verifier does not equal auditor or public accountant. Internal auditing of systems and procedures and a statement by the board of directors or chief executive officer are approaches that can be used in conjunction with independent verification to build stakeholder trust (GRI, 2000).

No generally accepted set of verification standards exist yet. The GRI provides guidelines on the form and content of verifiers' statements/reports (GRI, 2000) that are consistent with the considerations and form of an audit opinion. The report should identify the subject matter being verified, the date of the report and the medium that contains the report. There should be an indication that the reported subject matter is the responsibility of management and what the purpose of the verification is. The nature and source of the criteria implemented in the verification should be specified and any procedures or standards followed should be detailed. The qualifications of the verifiers should be disclosed as well as the date and place of issuing the report. A final specification indicates that the report should include "a statement or opinion as to the conclusions reached and an indication of the level of assurance provided about the subject matter, including any reservations or limitations" (GRI, 2000,49).

Beets and Souther (1999) have called for additional standards for environmental assurance services by external auditors. Currently environmental auditing is mainly an internal audit function although environmental costs (especially environmental liabilities) have financial reporting impacts (Kite, et al., 1996). 


\section{STAKEHOLDER THEORY AND DISCLOSURE LEVELS}

The GRI Guidelines attempt to serve the wider stakeholder information needs and not solely focus on needs of owners. Stakeholders are broadly defined as "any individual, group, or item that can affect or is affected by an organization's decisions" (AA, 1992, 35). This definition includes impacts in two directions, both on the organization itself and the organization's impacts on others.

Stakeholders may be further categorized as either primary or secondary stakeholders (Carroll, 1993; Gibson, 2000). Primary stakeholders have a formal, official, or contractual relationship with the company. All other stakeholders are secondary stakeholders and thus comprise a wide and diverse group. Secondary stakeholders have the latent potential to significantly impact a company in either a positive or negative manner so management should consider their interests (Gibson, 2000). Dierkes and Antal (1985) consider publicly disclosed corporate responsibility information to be a basis for dialogue with various stakeholders or business constituencies.

Theoretical support for the importance of social responsibility reporting comes from Freeman's (1983) business policy model that focuses on cultivating approval by stakeholders whose positive evaluation is needed for the company to be a going concern. Management's role is to assess stakeholder demands in terms of the company's strategic objectives. Increased stakeholder power increases the need to meet those demands.

Ullmann's (1985) conceptual framework considers (1) a stakeholder's power over resources the company requires, (2) the company's strategic posture toward corporate social responsibility activities, and (3) the company's past and current economic results. Greater disclosure is expected when stakeholder resources are vital to the company. Economic success impacts the company's continued existence and ability to carry out social responsibility programs. Thus given certain levels of stakeholder power and strategic posture, an increase in economic success will yield increased social responsibility activities and disclosures.

Roberts (1992) empirically tested Ullmann's (1985) framework and found that higher stakeholder power as measured for governmental and regulatory influences and creditor influences did result in increased disclosure, as did a more active strategic posture towards stakeholders.

Neu, et al. (1998) found public pressure had a positive influence on disclosure level. Company image was managed through communication instead of changing the firm's output, goals, or operating methods. Environmental disclosure was mainly directed at governmental regulators to try to reduce regulatory action by cultivating a good environmental citizen image. Other social disclosures and environmental disclosures appeared to be complements rather than substitutes; however, in environmentally sensitive industries other social disclosures were not as salient as they have less of an impact upon risk and return.

GRI Guidelines were used by Raar (2002) to analyze the environmental disclosure in annual reports of Australian companies. In content analysis methodology, themes are used to categorize the substance of a report according to the context of the themes (Holsti, 1969). A single country study holds constant the societal values and political and legal system variables found to influence social accounting disclosure (Williams, 1998; Adams, et al., 1998).

The annual reports were drawn from a required governmental reporting site so the page size, font and format were standardized. The governmental site did not include pictures in the accepted format. Little detail about environmental disclosures was found. Quality of disclosure was primarily narrative with some minor use of monetary and non-monetary measures. Greater reporting was found in industries that were considered environmentally risky or consumer focused.

Roberts (2004) used content analysis methodology on GRI reports in the petroleum industry (considered an environmentally risky industry by Raar, 2002). The qualitative weights were those used in Raar (2002) but as these were GRI reports the information was already in GRI themes. GRI does not have a mandated format and reporters included non-textual, pictorial matter in their reports. There was a statistically significant relationship between a high 
number of pictures and low quality of GRI reporting of the in accordance categories. This finding supports use of GRI reports as greenwashing for an environmentally challenged industry.

\section{METHODOLOGY}

Content analysis (Holsti, 1969, Raar, 2002) is used to evaluate the substance of the GRI reports and to ascertain any reporting tendencies. The presence or absence of each GRI category necessary for "in accordance" reporting will be noted and based upon the company's term for the category. Both quantitative and qualitative aspects of the reports will be examined as described below.

Non-textual matter was divided into three categories: pictures, graphs, and schedules. Pictures included both photographs and drawings that did not convey interrelationships between data. Graphs were visual items that conveyed interrelationships between data and included pie charts and bar graphs. Schedules were lists of items that included textual categories and quantitative measures (either monetary or non-monetary).

\section{Quantity Of Disclosure}

Raar (2002) used a source that provided uniform font and page size reports. As the GRI reports are voluntary, web-based, and international there is no standard font or page size. The amount of white space and margin size is not standard either. Due to this measurement issue quantity of disclosure will be measured as report length in pages as indicated by Adobe Acrobat Reader.

The number of pictures, graphics, and schedules will be ascertained. The number of pages of each type of non-textual material and text for the three main GRI categories of economic, environmental, and social category's representation will be determined. A percentage of total pages measure will be used to facilitate comparison as the reports are of uneven lengths.

\section{Quality Of Disclosure}

The quality of disclosure reflects how the disclosure is measured: monetary, non-monetary, or descriptive/narrative. Weights assigned to the types of disclosure are as used in Raar (2002) and shown in Table 1.

Table 1

Quality of Disclosure Definitions

\begin{tabular}{|l|l|c|}
\hline Nature of Disclosure & \multicolumn{1}{|c|}{ Definition } & \multicolumn{1}{|c|}{ Weight } \\
\hline Monetary & Currency/Monetary Unit & 2 \\
\hline Non-monetary & $\begin{array}{l}\text { Non-financial quantitative measures, } \\
\text { such as weight, or volume }\end{array}$ & 3 \\
\hline Qualitative only & Narrative description only & 4 \\
\hline Qualitative and Monetary & Narrative description and Currency & 5 \\
\hline Qualitative and Non-monetary & $\begin{array}{l}\text { Narrative description and Non-financial } \\
\text { quantitative measures }\end{array}$ & 6 \\
\hline Monetary and Non-monetary & $\begin{array}{l}\text { Currency and Non-financial quantitative } \\
\text { measures }\end{array}$ & 7 \\
\hline $\begin{array}{l}\text { Qualitative, Monetary and } \\
\text { Non-monetary }\end{array}$ & $\begin{array}{l}\text { Narrative description, Currency, and } \\
\text { Non-financial quantitative measures }\end{array}$ & \\
\hline
\end{tabular}

Higher weights are assigned to non-monetary disclosure and descriptive disclosure as many social and environmental issues are economic externalities that are difficult to measure in monetary units. The highest ranking is for integrative reporting that includes all three types of measurement and these measures illustrate the link between social and environmental issues and financial results (Raar, 2002). Economic disclosure indicators were only included in the results if in the GRI report itself, not in a separate financial report. 
The GRI categories necessary for "in accordance" reporting were used as the themes for the content analysis. There are three required general categories: Vision and Strategy: including CEO Statement; Profile of Reporting Organization; and Governance Structure and Management Systems. These three categories have a maximum quality score of 21 (3 indicators X 7 quality points as per Table 1).

The GRI core performance indicators include ten economic indicators with a maximum quality score of 70 . There are 16 core environmental indicators for with a maximum 112 quality score. The social category has 24 core indicators for a 168 maximum quality score. The social category is divided into four sub-categories: Labor Practices and Decent Work (11 core indicators, 77 points); Human Rights (7 core indicators, 49 points); Society (3 core indicators, 21 points); and Product Responsibility (3 core indicators, 21 points).

The percentage of the maximum possible reporting quality points per the rating scheme in Table 1 will be ascertained for each company.

\section{RESULTS}

Five companies comprise the entire population of Portuguese GRI reporters. The small population precluded statistical analysis, thus the results are descriptive in nature.

\section{Sample Selection}

Companies listed on the GRI website as GRI reporters from Portugal comprise the sample/population. The list of reporters is updated weekly and all Portuguese reporters listed as of July 14, 2005, are included. Listing on the GRI Website is voluntary and instigated by the company, so it is possible some guideline users may not be reflected. The GRI website provides links to the individual company's reports/websites and issues press releases about new reporters. Companies receive a public relations benefit so it is reasonable to conclude that the GRI website has a fairly comprehensive list of reporters.

The number of GRI reporters in European Union member states was examined to place the number of Portuguese reporters into context. Table 2 shows the number of GRI reporters from each European Union country.

Table 2

European Union GRI Reporters

\begin{tabular}{|l|c|l|c|}
\hline $\begin{array}{l}\text { Countries in European } \\
\text { Union }\end{array}$ & Number of GRI Reporters & $\begin{array}{l}\text { Countries in European } \\
\text { Union }\end{array}$ & Number of GRI Reporters \\
\hline Austria & 17 & Latvia & 0 \\
\hline Belgium & 8 & Lithuania & 0 \\
\hline Cyprus & 1 & Luxembourg & 0 \\
\hline Czech Republic & 0 & Malta & 42 \\
\hline Denmark & 5 & Netherlands & 1 \\
\hline Estonia & 0 & Poland & 5 \\
\hline Finland & 26 & Portugal & 0 \\
\hline France & 32 & Slovakia & 0 \\
\hline Hungary & 5 & Slovenia & 70 \\
\hline Germany & 33 & Spain & 24 \\
\hline Greece & 4 & Sweden & 91 \\
\hline Ireland & 3 & United Kingdom & \\
\hline Italy & 22 & & \\
\hline
\end{tabular}


In addition to Portugal, there are fourteen other countries with five or less GRI Reporters. Eastern European countries have no reporters and the United Kingdom, Spain, and the Netherlands have the three highest number of reporters. The GRI Secretariat is located in The Netherlands which may contribute to the high number of its GRI users. Given the large number of companies in these countries adoption of the GRI is not extensive. Although the English language version of the GRI Guidelines has been available since issuance in 2002, the Portuguese translation was issued in November 2004 (EDP, 2004).

The following companies comprise the Portuguese GRI reporters: Brisa S.A., Delta Cafes, EDP (Energias de Portugal), Portugal Telecom, and Sonae Sierra. Using the GRI website sector categories the companies represent: automotive, Brisa (constructs motorways); food and beverage products, Delta; energy utilities, EDP - Energias de Portugal; telecommunications, Portugal Telecom; and other, Sonae Sierra (owns shopping and leisure centers). Delta Cafes was an outlier but the other companies had specific GRI reports using Adobe Acrobat files on their company websites as the method of presentation.

Delta Cafes is listed on the GRI website; however, their report does not make use of or mention the GRI standards. The 'report' consisted of two PDF files that referred to SA 8000 Certification of Social Responsibility. One file described SA 8000 and the other file provided brief information about implementation of the standard. It resembles a press release as it states that Café Deltas was the first Portuguese company to do SA 8000 but does not provide specific implementation details. The report contained no pictures, graphs, or schedules and no economic or environmental indicators. There is no reference year in the report and thus would be likely to not meet CorporateRegister.com's threshold for a report (see quote on page 4 of this paper).

The other four companies had more complete GRI reports and the full analysis could be performed. All companies provided the economic information first. Two companies presented the environmental information second (Brisa and EDP) while the other two companies (Portugal Telecom and Sonae Sierra) provided the social information second.

\section{Quantity Of Disclosure}

Report length varied from five pages of all text for Delta Cafes to 124 pages for Portugal Telecom. Portugal Telecom had 32.15 pages of non-text (26\% of total report) and made substantial use of white space. Visually Portugal Telecom was the most striking with vivid colors and graphics. EDP's report was 98 pages of which 30.83 pages or $31.5 \%$ percent were non-text. Brisa's report was 85 pages, including 18.35 pages $(21.5 \%)$ non-text. Sonae Sierra's report was 36 pages long and featured 12.05 pages of non-text (33\%).

Detail about the type and extent of non-textual and textual disclosure is shown in Table 3. The percentage of the report that is devoted to graphics, pictures, schedules and text is shown for each of the three GRI categories. The percentage of the maximum quality points for the GRI category is shown for comparison of quantitative and qualitative disclosure. Delta Cafes is not shown as it did not use the GRI categories.

Panel A shows the economic disclosure results. The company with the highest quality result, Portugal Telecom, primarily used graphics and text to communicate. Sonae Sierra and Brisa used text as their main communication channel. All companies rarely used pictures in their economic disclosure. Only EDP made extensive use of schedules (63.6\%). The other companies used schedules very infrequently which is somewhat surprising considering the wide acceptance and use of schedules in financial reporting. 
Table 3

Analysis of Non-Textual and Textual Contents

Panel A: Economics Disclosure

\begin{tabular}{|l|c|c|c|c|}
\hline & Brisa & EDP & Telecom & Sonae \\
\hline Graphics Pages \% & $8.7 \%$ & $10.0 \%$ & $46.5 \%$ & $25.5 \%$ \\
\hline Pictures Pages \% & $3.3 \%$ & $2.0 \%$ & $3.5 \%$ & $7.5 \%$ \\
\hline Schedules Pages \% & $8.0 \%$ & $63.6 \%$ & $9.2 \%$ & $2.5 \%$ \\
\hline Text Pages \% & $80.0 \%$ & $24.4 \%$ & $40.8 \%$ & $65.0 \%$ \\
\hline $\begin{array}{l}\text { Maximum Quality } \\
\text { Points Percentage }\end{array}$ & $5.7 \%$ & $14.3 \%$ & $45.7 \%$ & $25.7 \%$ \\
\hline
\end{tabular}

Panel B: Social Disclosure

\begin{tabular}{|l|c|c|c|c|}
\hline & Brisa & EDP & Telecom & Sonae \\
\hline Graphics Pages \% & $20.6 \%$ & $11.6 \%$ & $10.4 \%$ & $13.0 \%$ \\
\hline Pictures Pages \% & $21.2 \%$ & $4.7 \%$ & $8.3 \%$ & $13.5 \%$ \\
\hline Schedules Pages \% & $24.7 \%$ & $0.6 \%$ & $5.3 \%$ & $3.5 \%$ \\
\hline Text Pages \% & $33.4 \%$ & $83.1 \%$ & $76.0 \%$ & $70.0 \%$ \\
\hline $\begin{array}{l}\text { Maximum Quality } \\
\text { Points Percentage }\end{array}$ & $44.6 \%$ & $38.4 \%$ & $45.8 \%$ & $21.7 \%$ \\
\hline
\end{tabular}

\section{Panel C: Environmental Disclosure}

\begin{tabular}{|l|c|c|c|c|}
\hline & Brisa & EDP & Telecom & Sonae \\
\hline Graphics Pages \% & $0.0 \%$ & $7.1 \%$ & $17.6 \%$ & $24.2 \%$ \\
\hline Pictures Pages\% & $12.7 \%$ & $17.5 \%$ & $6.9 \%$ & $3.3 \%$ \\
\hline Schedules Pages\% & $8.0 \%$ & $57.7 \%$ & $13.1 \%$ & $28.3 \%$ \\
\hline Text Pages \% & $79.3 \%$ & $17.7 \%$ & $62.4 \%$ & $44.2 \%$ \\
\hline $\begin{array}{l}\text { Maximum Quality } \\
\text { Points Percentage }\end{array}$ & $31.3 \%$ & $38.4 \%$ & $37.5 \%$ & $22.3 \%$ \\
\hline
\end{tabular}

Panel B shows the social disclosure results and text was the largest percentage for all companies. In a category that would seem a natural one for lots of pictures of people two companies (EDP and Portugal Telecom) had less than 10 percent pictures. Only Brisa had more than 20 percent pictures $(21.2 \%)$ and made comparable use of graphics and schedules.

Panel $\mathrm{C}$ shows the environmental disclosure results. Two of the companies with the highest quality results, Brisa and Portugal Telecom, chose to primarily communicate through text. EDP had a high quality result but used schedules predominately supplemented equally by text and pictures. Graphics were not popular with any company but Sonae Sierra who used a significant amount of graphics throughout their GRI report.

\section{Quality Of Disclosure}

Quality of GRI disclosure was computed as described above. Economics was the highest category for Portugal Telecom and for Sonae Sierra. Financial reporting is a required activity thus this information is readily available. Lower economic reporting for the other companies may be due to the existence of the alternative source for this information, the annual report. Weights assigned in this category were primarily ones, monetary only. Portugal Telecom received the only 7, qualitative, monetary, and non-monetary, for the EC 6 Indicator, Distribution to providers of capital broken down by interest on debt and dividends. There were a few 4 weights, qualitative and monetary.

Environmental reporting was the not the highest category for any company although it tied with social reporting for EDP. With the possible exception of Brisa, the builder of motorways, none of the companies are in environmentally risky industries. This was Sonae Sierra's first year of including economics and social dimensions in 
their report and the company did a good job of a balanced presentation of all three categories. Across all companies, most of the weights assigned in this category were either 3 , qualitative only, and 5, qualitative and non-monetary.

Table 4

Quality of Category Indicators Disclosure: Maximum Quality Points Percentage

Panel A: All Major GRI Categories

\begin{tabular}{|l|c|c|c|c|c|}
\hline & Brisa S.A & EDP & Portugal Telecom & Sonae Sierra & Delta Cafes \\
\hline Economics & $5.7 \%$ & $14.3 \%$ & $45.7 \%$ & $25.7 \%$ & $0.0 \%$ \\
\hline Environmental & $31.3 \%$ & $38.4 \%$ & $37.5 \%$ & $22.3 \%$ & $0.0 \%$ \\
\hline Social & $44.6 \%$ & $38.4 \%$ & $45.8 \%$ & $21.7 \%$ & $5.4 \%$ \\
\hline
\end{tabular}

\section{Panel B: Society Sub-Category - Maximum Quality Points Percentage}

Panel B: Society Sub-Category - Maximum Quality Points Percentage
\begin{tabular}{|l|c|c|c|c|c|}
\hline & Brisa S.A & EDP & Portugal Telecom & Sonae Sierra & Delta Cafes \\
\hline $\begin{array}{l}\text { Total Labor practices } \\
\text { and decent work }\end{array}$ & $46.8 \%$ & $59.7 \%$ & $49.4 \%$ & $31.2 \%$ & $0.0 \%$ \\
\hline Total Human rights & $42.8 \%$ & $30.6 \%$ & $42.8 \%$ & $0.0 \%$ & $12.2 \%$ \\
\hline Total Society Indicators & $42.9 \%$ & $14.3 \%$ & $42.9 \%$ & $28.6 \%$ & $14.3 \%$ \\
\hline $\begin{array}{l}\text { Total Product } \\
\begin{array}{l}\text { Responsibility } \\
\text { Indicators }\end{array}\end{array}$ & & & & \\
\end{tabular}

Social reporting was the highest category for Brisa and Portugal Telecom and it tied with environmental reporting for EDP. As the GRI divided social reporting into four sub-categories, the quality score obtained by the company was divided by the total possible for that specific sub-category to yield the results show in Table 4 Panel B. Delta Cafes is included in this table as it did have some social reporting.

Three out of five companies did not report in all sub-categories. Both Brisa and Portugal Telecom had consistent levels of quality reporting. EDP focused primarily on labor practices and decent work and moderate coverage of human rights. Sonae Sierra did not report any human rights indicators but had fairly even coverage of the remaining three sub-categories.

All human rights, society, and product responsibility sub-category reporting were weight 3 , qualitative only. Labor practices included some weight 3 , qualitative only, disclosure but also included some weight 5 , qualitative and non-monetary, disclosure as well.

All four of the GRI reporters had their reports verified but only one company (EDP) used a public accounting firm. Brisa used an internal verification instead of an independent external verifier. This gives less credibility than an external verification. Telecom and Sonae Sierra used companies that specialize in this form of verification. Portugal Telecom used SGS ICS, a worldwide assessment and verification firm. SGS ICS specializes in certification of services, quality, ethical issues auditing procedures, and environmental and social management systems. Sonae Sierra used Upstream, a UK-based advisor on strategic sustainability (Sonae Sierra is $50 \%$ owned by UK interests). It would appear the public accounting firms are not capitalizing on an emerging practice opportunity.

\section{CONCLUSIONS AND LIMITATIONS}

Organizational stakeholder status is not required for listing of a company's report on the GRI website. For companies with greater than 1,000,000 euro in sales, the annual organizational stakeholder fee is 10,000 euros. (For smaller companies there is a sliding fee scale from 5,000 to 100 euros.) The existence of two organizational stakeholders, Brisa and EDP, 40 percent of the Portuguese GRI reporters, shows strong interest in and support of GRI reporting. Portuguese reporting levels are in line with European Union adopters of GRI and the guidelines were only 
translated into Portuguese at the end of 2004. GRI reporting is in its infancy in Portugal but the outlook appears positive.

For the Portuguese companies that used the GRI Guidelines each one made a substantial attempt to fulfill the Guidelines. (Delta Cafes is not included in this remark as it referenced SA 8000 instead of GRI Guidelines.) Environmental reporting was not the emphasis for Portuguese companies. Social reporting and economic reporting were stressed and in particular social reporting was strong and covered the majority of the social sub-categories. Nontextual communication seemed appropriate as no overly sentimental photographs were used to misdirect the reader from the textual content (the statistically significant situation in the petroleum industry GRI report study, Roberts, 2004).

Analysis of weights including qualitative disclosure was neutral, that is, the presence of narrative description qualified in the weighting scheme. From reading of the wording however, not all narrative description addressed the indicator as substantively. Portugal Telecom would have received much lower quality of GRI reporting results had some subjective evaluation of the narrative been performed. Such an evaluation would be difficult to replicate but perhaps inter-rater reliability measures could be used in future studies that included this dimension.

The small number of companies is a limitation as it did not allow for statistical analysis; however, a single country study does hold constant societal values and political and legal system variables. Future studies could focus on a single country with a greater number of reporters. Additionally, multiple years of reports could be analyzed to discern the trends in GRI reporting.

\section{REFERENCES}

1. Adams, C.A, W.Y. Hill and C. Roberts. 1998. Corporate social reporting practices in Western Europe: legitimating corporate behavior? British Accounting Review, (30, 1): 1-21.

2. Arthur Andersen \& Co., SC. 1992. Business Ethics Program, Accounting Materials. Arthur Andersen \& Co., SC.: St. Charles, IL.

3. Beets, S. D. and C. C. Souther. 1999. Corporate Environmental Reports: The Need for Standards and an Environmental Assurance Service. Accounting Horizons. (13, 2): 129-145.

4. Carroll, A. 1993. Business and Society: Ethics and Stakeholder Management Southwestern Publishing: Cincinnati.

5. CorporateRegister.com, 2004, A register of steps towards sustainable business, www.corporateregister.com/faq.html.

6. Dierkes, M. and A. Antal. 1985. Whiter Corporate Social Reporting: Is It Time to Legislate? California Management Review. 106-120.

7. $\quad$ EDP (Energias de Portugal). 2004. Annual Report Sustainability Report. www.edp.pt/index.asp?MID=2\&CID=106000\&LID=en

8. Freeman, R. 1983. Strategic Management: a Stakeholder Approach. Advances in Strategic Management. 3160.

9. Gibson, K. 2000. The moral basis of stakeholder theory. Journal of Business Ethics. August. 245-257.

10. Global Reporting Initiative. 2000. A Common Framework for Sustainability Reporting. www.globalreorting.org.

11. Global Reporting Initiative. 2002. Companies using the GRI Sustainability Reporting Guidelines. www.g1oba1reporting.org/GRIGuidelines/Reporters.htm.

12. Gordon, I. 1998. Enhancing Students' Knowledge of Social Responsibility Accounting. Issues In Accounting Education (13, 1): 31-46.

13. Holsti, O. R., 1969. Content Analysis for the Social Sciences and Humanities, Addison-Wesley Publishing Company, Philippines.

14. Kite, D., T. J. Louwers, and R. R. Radtke. 1996. Ethics and Environmental Auditing: An Investigation of Environmental Auditors' Levels of Moral Reasoning. Behavioral Research in Accounting, (8 Supplement): 200-2 14 . 
15. Laufer, W. S., 2003, Social Accountability and Corporate Greenwashing, Journal of Business Ethics, 43, 3, pp. 253-260.

16. Neu, D., H. Warsame, and K. Pedwell. 1998. Managing Public Impressions: Environmental Disclosures In Annual Reports. Accounting, Organizations and Society. (23, 3): 265-282.

17. PricewaterhouseCoopers. 2002. PricewaterhouseCoopers Increases its Commitment to Promoting Corporate Social Responsibility. www.pwcglobal.com

18. Raar, J., 2002. Environmental Initiatives: towards triple-bottom line reporting, Corporate Communications, 7, 3, pp. 169-183.

19. Roberts, D. H. 2004. Sustainability Reporting Practices in the Oil and Gas Industry: Corporate Greenwashing or Triple Bottom Line? Paper presented at the European Applied Business Research Conference, Edinburgh, Scotland.

20. Roberts, R. W. 1992. Determinants of Corporate Social Responsibility Disclosure: An Application of Stakeholder Theory. Accounting, Organizations and Society. (17, 6): 595-612.

21. Sefcik, S. E., N. S. Soderstrom, and C. H. Stinson. 1997. Accounting Through Green-Colored Glasses: Teaching Environmental Accounting. Issues In Accounting Education Spring): 129-140.

22. Ullmann, A. 1985. Data in Search of a Theory: a Critical Evaluation of the Relationship Among Social Performance, Social Disclosure, and Economic Performance. Academy of Management Review. 540-577.

23. Williams, S.M. 1998. Impact of societal variables on voluntary environmental and social accounting disclosure practices: an empirical study. Paper presented at the AAANZ Conference, Hobart.

\section{$\underline{\text { NOTES }}$}


International Business \& Economics Research Journal - September 2007

Volume 6, Number 9

\section{NOTES}

